\title{
MODEL KOMUNIKASI PENEGAK HUKUM DALAM RUANG PERSIDANGAN DI PENGADILAN NEGERI JAKARTA PUSAT
}

\author{
Aan Widodo \\ Fakultas Ilmu Komunikasi, Universitas Bhayangkara Jakarta Raya \\ J1. Darmawangsa I No. 1, Kebayoran Baru, Jakarta Selatan, DKI Jakarta, 12140, Indonesia \\ No. Telp/HP: 081224031809 \\ E-mail: aan.widodo@dsn.ubharajaya.ac.id
}

Naskah diterima pada tanggal 5 September 2019 direvisi tanggal 3 Oktober 2019 disetujui tanggal 18 Oktober 2019

\section{COMMUNICATION MODEL OF LAW ENFORCEMENT OFFICIALS IN CENTRAL JAKARTA DISTRICT COURT}

\begin{abstract}
The trial is one of the communication contexts in law enforcement. The process of law enforcement through trials contains aspects of messages, communicators, and purpose of communication as well as the unique communication events, which seen from the language and the communication process. The purpose of this study is to map the communication models for law enforcement in court as part of the law enforcement process. The approach used is qualitative research with ethnography of communication method. Data was obtained from participatory observation, interviews with informants, and document analysis in the Central Jakarta District Court. The result showed that the roles, interests, goals, and types of communication actors distinguished communication events in the trials. Communication actors as law enforcers at the trials consist of Judges, Public Prosecutors, and Legal Advisors who are interacting and communicating with each other. Interaction and communication in the trials in the study of communication ethnography theory developed communication models. The communication models are: (1) The law enforcement communication model in the courtroom consists of the communication of the judges, the communication model of the prosecutor, and the legal advisor communication model; (2) Communication model among law enforcers in the courtroom.
\end{abstract}

Keywords: law enforcement, trials, communication model.

Abstrak. Persidangan merupakan salah satu konteks komunikasi dalam penegakan hukum. Proses penegakan hukum melalui persidangan mengandung aspek pesan, pelaku dan tujuan komunikasi, serta peristiwa komunikasi yang khas, dilihat dari bahasa dan proses komunikasinya. Tujuan penelitian ini adalah untuk memetakan model komunikasi penegak hukum dalam persidangan sebagai bagian dari proses penegakan hukum melalui pengadilan. Pendekatan yang digunakan adalah pendekatan kualitatif dengan metode etnografi komunikasi. Data diperoleh dengan melakukan observasi partisipatif, wawancara dengan informan, dan studi dokumentasi di Pengadilan Negeri Jakarta Pusat. Hasil penelitian ini menunjukkan bahwa peristiwa komunikasi dalam persidangan dibedakan berdasar peran, kepentingan, tujuan, dan tipe pelaku komunikasi. Pelaku komunikasi sebagai penegak hukum dalam persidangan terdiri dari hakim, penasihat hukum dan penuntut umum yang saling berinteraksi dan berkomunikasi. Interaksi dan komunikasi dalam persidangan dalam kajian teori etnografi komunikasi menghasilkan model komunikasi. Model komunikasi tersebut ialah: (1) Model komunikasi penegak hukum dalam persidangan, terdiri dari model komunikasi hakim majelis, model komunikasi penuntut umum, serta model komunikasi penasihat hokum; (2) Model komunikasi antarpenegak hukum dalam persidangan.

Kata kunci: penegak hukum, persidangan, model komunikasi.

DOI: $10.20422 / j p k . v 22 i 2.660$ 


\section{PENDAHULUAN}

Peristiwa komunikasi dalam berbagai konteks persidangan tidak dapat dipisahkan dari proses komunikasi, yang menggambarkan berlangsungnya interaksi komunikasi dalam peristiwa tertentu. Interaksi komunikasi yang terjadi dalam peristiwa komunikasi dapat dilihat dari proses komunikasi sebagai sebuah konteks, seperti peristiwa komunikasi dalam persidangan. Persidangan merupakan konteks komunikasi yang memiliki kekhususan dibandingkan dengan konteks komunikasi lainnya. Dalam penegakan hukum, proses komunikasi antara pihak-pihak yang terlibat dalam persidangan menggambarkan bagaimana peristiwa komunikasi dalam penegakan hukum berlangsung dalam dunia peradilan.

Penegakan hukum dalam persidangan cukup kompleks dibandingkan dengan konteks komunikasi lain. Setiap orang yang terlibat dalam persidangan memiliki tujuan, kepentingan dan peran yang berbeda. Meskipun secara umum persidangan memiliki kesamaan aspek tujuan hukum yakni keadilan bagi terdakwa maupun korban.

Salah satu aspek penting dalam mencapai tujuan keadilan tersebut ialah melalui komunikasi. Komunikasi dilakukan oleh pihak penegak hukum yang terlibat dalam persidangan, yaitu pihak hakim, pihak terdakwa, pihak penasihat hukum dan pihak penuntut umum. Komunikasi yang dilakukan dalam persidangan tersebut melibatkan pesan baik secara verbal maupun nonverbal, sebagai inti dari komunikasi dalam persidangan sebagaimana pesan merupakan inti dari komunikasi (Mulyana, 2013).

Komunikasi dalam persidangan didukung aspek-aspek komunikasi, yakni terdapat pelaku komunikasi, pesan yang dipertukarkan dan tujuan yang ingin dicapai. Sebagaimana pemahaman dasar bahwa sebuah proses komunikasi melibatkan berbagai aspek sedikitnya terdapat aspek pelaku, pesan, dan tujuan komunikasi (Mulyana, 2010, 2013). Berdasarkan hasil pengamatan peneliti, secara umum ketiga aspek yang dimaksud terdiri dari penegak hukum (hakim, penuntut umum, penasihat hukum) sebagai pelaku komunikasi; komunikasi verbal (tanya jawab, interupsi, jawab menjawab) dan komunikasi nonverbal (nada suara, gerakan tubuh, gelengan kepala) serta komunikasi lisan (penyataan, sanggahan, permohonan) dan komunikasi tulisan (surat-menyurat, berkas pemeriksaan, berkas-berkas) sebagai pesan komunikasi yang dipertukarkan; serta pemeriksaaan perkara guna membuktikan terdakwa bersalah atau tidak dan kemudian dihukum secara adil sebagai tujuan komunikasi. Komunikasi demikian berdasarkan tujuan komunikasi disebut sebagai interaksi pengadilan (courtroom interactions) (Beach, 1985).

Courtroom interactions merupakan sebuah konteks komunikasi. Dalam hal ini konteks komunikasi terjadi dalam persidangan. Sebagai sebuah rangkaian yang utuh dan berkesinambungan, persidangan didefinisikan sebagai sebuah proses atau tahapan dalam penegakan hukum melalui persidangan. Penegakan hukum yang dimaksud melibatkan interaksi komunikasi antarpelaku komunikasi guna mencapai tujuan komunikasi menggunakan pesan-pesan komunikasi. Interaksi komunikasi yang berlangsung secara terus menerus melahirkan sebuah model komunikasi sebagai salah satu implementasi persidangan sebagai sebuah proses dan konteks komunikasi.

Model komunikasi yang dimaksud terfokus pada definisi aspek komunikasi sebagaimana yang telah diungkapkan. Penelitian ini dilakukan untuk menjawab pertanyaan bagaimana model komunikasi penegak hukum dalam persidangan di pengadilan. Sementara itu tujuan penelitian ini adalah untuk mendeskripsikan persidangan dalam sudut pandang komunikasi salah satunya melalui gagasan model komunikasi. Penelitian ini dilakukan sebagai bagian dari pengembangan keilmuan komunikasi yang bersifat multidisiplin.

\section{LANDASAN KONSEP}

\section{Komunikasi dalam Persidangan}

Komunikasi dalam persidangan merupakan bentuk komunikasi yang dilihat dari konteks komunikasi di mana Beach (1985) menyebutnya sebagai interaksi 
pengadilan. Interaksi ini merupakan proses komunikasi yang dipertukarkan dalam memeriksa perkara guna membuktikan terdakwa dapat dipersalahkan atau tidak dan kemudian dihukum secara adil sebagai tujuan komunikasi. Interaksi pengadilan yang diorganisasikan dengan beberapa cara dengan tujuan mengungkapkan/memeriksa secara jelas kejadian yang melibatkan dugaan kriminal. Misalnya ketika pengacara menginterogasi saksi dalam kesaksian di pengadilan. Beberapa cara yang dimaksud melalui observasi dan interogasi yang bertujuan untuk mengonstruksi realitas masa lalu, keadaan atau pengaturan yang tidak teramati melalui upaya interaksi (Beach, 1985).

Persidangan di pengadilan Indonesia pun demikian. Setidaknya dua cara tersebut dilakukan. Dalam persidangan masingmasing pihak mengutarakan ide, gagasan, pandangan, melalui peran yang dilakukan guna mencapai tujuan yang diinginkan. Banyak hal dan faktor yang melatarbelakangi bagaimana seseorang berkomunikasi dalam persidangan.

Menurut Masyarakat Pemantau Peradilan Indonesia (2018) antara lain perbedaan budaya, nilai, keyakinan, kebiasaan, dialek yang digunakan, karakteristik pribadi, hingga bias-bias terkait dengan konstruksi gender, yang akan berdampak pada bagaimana seseorang menyimpulan sebuah perkara (MaPPI, 2018). Komunikasi dalam persidangan sebagai bentuk komunikasi pemeriksaan/interogasi (investigation). Pemeriksaan dilakukan dalam tahapan persidangan dan proses persidangan.

\section{Komponen Komunikasi}

Berdasarkan penelusuran istilah komponen kerap disamakan dengan istilah unsur sehingga ada beberapa literatur menyebut komponen komunikasi adalah unsur komunikasi (Cangara, 2014; Devito, 2013). Bila merujuk Cangara (2014), unsur komunikasi terdiri dari komunikator, pesan, media, komunikan, efek, serta umpan balik dan merupakan bentuk dari model linear. Bila ditelisik, sebenarnya unsur komunikator dan komunikan dalam perspektif model transaksional dimaksud adalah pelaku komunikasi sehingga komponen komunikasi terdiri dari pelaku komunikasi, pesan yang dipertukarkan dan tujuan komunikasi (Mulyana, 2013).

Proses komunikasi dalam penelitian ini dilihat dari perspektif model transaksional dengan memandang bahwa proses komunikasi dalam persidangan bersifat aktif. Bersifat aktif yang dimaksud bahwa terjadi proses komunikasi yang berlangsung simultan dan dinamis, pelaku komunikasi dianggap aktif, kreatif sehingga respon sulit untuk diprediksi. Lain halnya dengan proses komunikasi yang bersifat pasif. Berkebalikan dari aktif, proses komunikasi pasif menimbulkan respon yang sama, manusia dianggap pasif dan tidak dinamis sehingga respon mudah diprediksi.

Proses komunikasi dalam persidangan di pengadilan merupakan proses komunikasi yang aktif dengan melibatkan aspek komunikasi yang kompleks. Penggunaan model ini karena masing-masing pelaku komunikasi bertanggung jawab atas makna yang terjadi, sehingga proses komunikasi berlangsung secara terus-menerus hingga tujuan komunikasi tercapai.

\section{Teori Etnografi Komunikasi}

Etnografi komunikasi berfokus pada proses komunikasi sebuah masyarakat tutur (speech community). Etnografi komunikasi menganggap bahasa sebagai kendaraan makna dan jembatan komunikasi serta dimaknai secara bersama oleh orang-orang yang terlibat dan tergabung dalam kategori masyarakat tutur (memiliki budaya, bahasa, dan sistem komunikasi yang sama). Teori etnografi komunikasi merupakan pendekatan untuk menganalisis wacana yang berfokus pada perilaku komunikasi masyarakat tutur.

Komunikasi memiliki pola dan diatur sebagai sebuah sistem peristiwa komunikatif, dan cara-cara berinteraksi dengan sistem budaya (Littlejohn \& Foss, 2009; SavilleTroike, 2008). Etnografi komunikasi berusaha untuk: (1) menemukan berbagai bentuk dan fungsi yang tersedia untuk berkomunikasi; (2) menetapkan cara bentuk dan fungsi tersebut menjadi bagian dari cara hidup yang berbeda; (3) menganalisis pola komunikasi sebagai bagian dari pengetahuan budaya dan perilaku. 
Di dalam persidangan, budaya yang dimaksud adalah budaya komunikasi. Budaya komunikasi dalam peradilan mengarah kepada cara-cara yang dilakukan oleh penegak hukum dalam mencapai tujuannya. Cara tersebut diimplementasikan dengan dukungan aturan, artefak-artefak budaya yang memiliki makna. Misalnya posisi tempat duduk penegak hukum yang berbeda dan menunjukkan identitas, bahasa panggilan yang digunakan, hingga aturan komunikasi yang bersifat sentral pada salah satu penegak hukum.

Hymes (1974) dalam Littlejohn \& Foss (2009) memperkenalkan kerangka deskriptif yang berguna untuk memandu menemukan, memahami, dan mendeskripsikan sebuah peritiwa dan pola komunikasi dalam budaya masyarakat tutur. Kerangka ini diabstraksikan dalam akronim 'SPEAKING', yakni Setting and Scene (pengaturan tempat dan situasi psikologis); Participant (orang yang terlibat dalam interaksi dan relasinya satu sama lain); Ends (tujuan dan hasil dari interaksi dan komunikasi); Act Sequences (urutan tindak/bentuk komunikasi); Instrumentalities (saluran/kode komunikasi); Norms of interaction and intepretations aturan mengenai bagaimana orang harus berperilaku dan aturan untuk memastikan makna perilaku tertentu); Genre (kategori atau tipe tindakan dan kejadian pembicaraan) (Littlejohn \& Foss, 2009).

\section{METODE PENELITIAN}

Penelitian ini menggunakan pendekatan kualitatif dengan metode penelitian etnografi komunikasi. Pertimbangan pemilihan pendekatan kualitatif dengan metode etnografi komunikasi adalah karena penelitian ini memandang peristiwa persidangan sebagai peristiwa/fenomena komunikasi yang di dalamnya terdapat manusia sebagai subjek penelitian yang aktif, kreatif, dan dinamis. Sebagaimana pandangan dari Mulyana bahwa pendekatan kualitatif memandang subjek penelitian bersifat aktif juga dinamis serta tindakan individu tidak dapat digeneralisasi (Mulyana, 2017). Sementara pemilihan metode etnografi komunikasi didasarkan pada 142 fakta bahwa persidangan merupakan peristiwa budaya dan peristiwa bahasa masyarakat tutur yang khas, yang mana pihak-pihak dalam persidangan merupakan sekelompok orang yang memiliki bahasa bersama, dimaknai bersama dan digunakan bersama. Sebagai sebuah kelompok yang khas tersebut, maka persidangan dapat disebut sebagai kelompok tutur atau masyarakat tutur yang didefinisikan sebagai masyarakat atau kelompok yang memiliki bahasa bersama yang khas (Chaer, A., \& Agustina, 2004; Spradley, 2007).

Data penelitian ini diperoleh dengan menggunakan beberapa teknik pengumpulan data. Teknik pengumpulan data utama yang digunakan adalah observasi partisipatif, selain itu dilengkapi dengan wawancara mendalam dan studi dokumentasi. Observasi dilakukan selama kurun waktu tahun 2016 hingga tahun 2018 terutama pada beberapa persidangan yakni persidangan JSK juga persidangan STN (JSK dan STN merupakan inisial tersangka yang perlu untuk disamarkan, sebagaimana ketentuan penelitian perkara dalam peradilan). Kemudian wawancara tidak terstruktur dilakukan kepada pihak hakim majelis, penasihat hukum, penuntut umum dan terdakwa. Selain itu studi dokumentasi juga digunakan sebagai bagian dari teknik pengumpulan data dalam penelitian. Data yang telah diperoleh kemudian dianalisis dengan menggunakan teknik analisis data kualitatif dengan metode etnografi komunikasi, yakni melalui tahapan deskripsi data, analisis data, verifikasi data, dan penarikan simpulan.

\section{HASIL PENELITIAN DAN PEMBAHASAN}

Persidangan di pengadilan berlangsung di ruang sidang. Berdasarkan hasil observasi, ruang sidang di Pengadilan Negeri Jakarta Pusat terdiri dari 19 ruang sidang yang dibedakan berdasarkan ukuran ruang, yakni ruang sidang berukuran besar, ruang sidang berukuran sedang, dan ruang sidang berukuran kecil. Ruang sidang ini digunakan sebagai tempat untuk memeriksa perkara, adapun penggunaan ruang sidang disesuaikan 
dengan ukuran perkara, misalnya perkara kasus besar (menyangkut orang "penting", pejabat/politisi, dan kasus penting dan menyita perhatian masyarakat, misalnya kasus korupsi) menggunakan ruang sidang ukuran besar. Sementara kasus kecil menggunakan ruangan kecil (misalnya kasus penggunaan narkotika). Dalam penegakan hukum ruang sidang berfungsi sebagai ruang komunikasi/tempat terjadinya komunikasi.

Sebagai ruang tempat terjadinya komunikasi dalam persidangan, di Pengadilan Negeri Jakarta Pusat terdapat orang-orang yang berkomunikasi dan berinteraksi yakni para penegak hukum. Penegak hukum juga terlihat dalam persidangan pidana perkara terdakwa JSK dan STN. Mereka adalah hakim, penasihat hukum, dan penuntut umum yang berkomunikasi dalam persidangan. Berdasarkan wawancara yang dilakukan dengan informan, penegak hukum dalam persidangan adalah penegak hukum yang mewakili institusi, yakni hakim mewakili pengadilan, penasihat hukum mewakili terdakwa atau institusi advokat, sementara penuntut umum mewakili kepolisian/negara. Dalam penegakan hukum, mereka melakukan interaksi dan komunikasi yang dilakukan sebelum sidang, setelah sidang, dan saat sidang.

Penegakan hukum dalam persidangan pun melibatkan tujuan yang berbeda. Berdasarkan wawancara dari informan ditemukan terdapat dua klasifikasi tujuan, yaitu tujuan individu dan tujuan kelompok. Tujuan individu mengarah kepada tujuan masing-masing penegak hukum dengan melibatkan peran masing-masing, sementara tujuan kelompok yaitu tujuan untuk memeriksa perkara dan mendapatkan keadilan bagi terdakwa dan juga korban sesuai dengan ketentuan yang berlaku.

Untuk mencapai tujuan tersebut komunikasi dilakukan baik dalam bentuk komunikasi verbal maupun komunikasi nonverbal, hingga komunikasi lisan maupun tulisan. Berdasarkan hasil pengamatan peneliti, komunikasi verbal terjadi dalam bentuk tanya jawab, interupsi, jawab menjawab dan komunikasi nonverbal terjadi dalam bentuk nada suara, gerakan tubuh, gelengan kepala, anggukan kepala, suara pukulan, teriakan, hingga tangisan serta komunikasi lisan terjadi dalam bentuk penyataan, sanggahan, permohonan, hingga perintah, dan komunikasi tulisan dalam bentuk surat-menyurat, berkas pemeriksaan, berkas-berkas bukti perkara.

Komunikasi dalam persidangan juga berlangsung dalam tata aturan dan norma yang diatur KUHP. Misalnya mengenai penataan ruang, yang mencerminkan stratifikasi peran, di mana posisi paling depan mengindikasikan peran yang paling penting. Berdasarkan hasil penelitian dalam persidangan, peran dapat dilihat dari posisi duduk. Di antaranya pihak penuntut umum dan penasihat hukum memiliki tempat duduk yang sejajajar berhadapan. Hal ini menunjukkan kesamaan peran dalam persidangan. Lain halnya dengan saksi dan terdakwa yang berada di tengah persidangan yang menunjukkan bahwa keduanya menjadi objek yang diperiksa.

Komunikasi penegak hukum dalam persidangan yang dilakukan penegak hukum dengan menggunakan komunikasi verbal maupun nonverbal untuk mencapai tujuan yang diinginkan, dilakukan terus menerus hingga tujuannya tercapai melahirkan model komunikasi. Model-model komunikasi ditemukan adalah model komunikasi penegak hukum dalam persidangan dan model komunikasi antarpenegak hukum dalam persidangan. Persamaan model ini adalah terjadi di ruang sidang, dilakukan oleh penegak hukum, serta tujuan kelompok yang sama. Sementara perbedaan terletak pada kepentingan, peran dan tujuan individu masing-masing. Lebih lanjut diuraikan sebagai berikut:

\section{Model Komunikasi Penegak Hukum dalam Ruang Persidangan Model Komunikasi Hakim}

Model komunikasi hakim merupakan bentuk model komunikasi yang terjadi antara hakim majelis dalam persidangan. Hakim majelis merupakan kelompok hakim yang terdiri dari hakim ketua dan hakim anggota. Model komunikasi hakim majelis ini bertujuan untuk penyamaan persepsi/pandangan tentang kasus yang ditangani. Dalam sebuah perkara, sedikitnya 
tiga hakim yang menangani satu perkara dan paling banyak sembilan hakim.

Berdasarkan keterangan yang diperoleh dari informan, komunikasi hakim ini dimulai sebelum persidangan ditandai dengan diskusi mengenai:

1. Kesiapan menjalankan persidangan sebelum sidang dimulai, komunikasi ini biasanya terjadi di ruang hakim;

2. Komunikasi verbal dengan pertanyaan dan jawaban, terjadi ketika komunikasi pada saat pergantian anggota majelis, komunikasi ini terjadi di dalam ruang sidang, tepatnya di meja majelis hakim, komunikasi dalam bentuk verbal dan nonverbal. Biasanya komunikasi sangat cair dan tidak kaku, misalnya "setelah ini pindah ruangan mas?" atau "lanjut sidang ruang sebelah?”. Sementara komunikasi nonverbal biasanya ditunjukkan dengan mengarahkan telunjuk pada ruangan sidang sebagai lokasi berikutnya, atau gerak tubuh yang lainnya sambil berdiri dan membawa berkas. Contoh lain adalah komunikasi dengan tujuan perpindahan hakim anggota menjadi hakim ketua atau sebaliknya;

3. Komunikasi pada saat persidangan berlangsung, dalam bentuk tanya jawab, komunikasi ini terjadi ketika hakim ketua menanyakan kepada hakim anggota apakah pemeriksaan selesai, apabila dalam agenda pemeriksaan. Misalnya hakim ketua menanyakan apakah keterangan yang disampaikan terdakwa atau disampaikan penegak hukum lain dirasa cukup atau kurang. Sambil menoleh kepada hakim anggota yang dituju hakim ketua menanyakan hal tersebut. Apabila dirasa cukup hakim anggota menganggukkan kepala atau menjawab cukup;

4. Komunikasi pada saat mengomunikasikan hasil pemeriksaan, alat bukti, keterangan saksi dan musyawarah majelis. Komunikasi ini dilakukan untuk mencapai kesepakatan dalam menilai apakah bukti dianggap cukup atau keterangan dianggap sesuai sehingga dilanjutkan dengan musyawarah menentukan hukuman yang sesuai dengan hasil pemeriksaan dan tindak kejahatan terdakwa. Dalam musyawarah ini, masing-masing majelis hakim menyampaikan pandangan terkait selama proses persidangan berlangsung.

Berdasarkan identifikasi hasil observasi dan wawancara, model komunikasi antara majelis hakim pada akhirnya melahirkan model sebagai berikut.

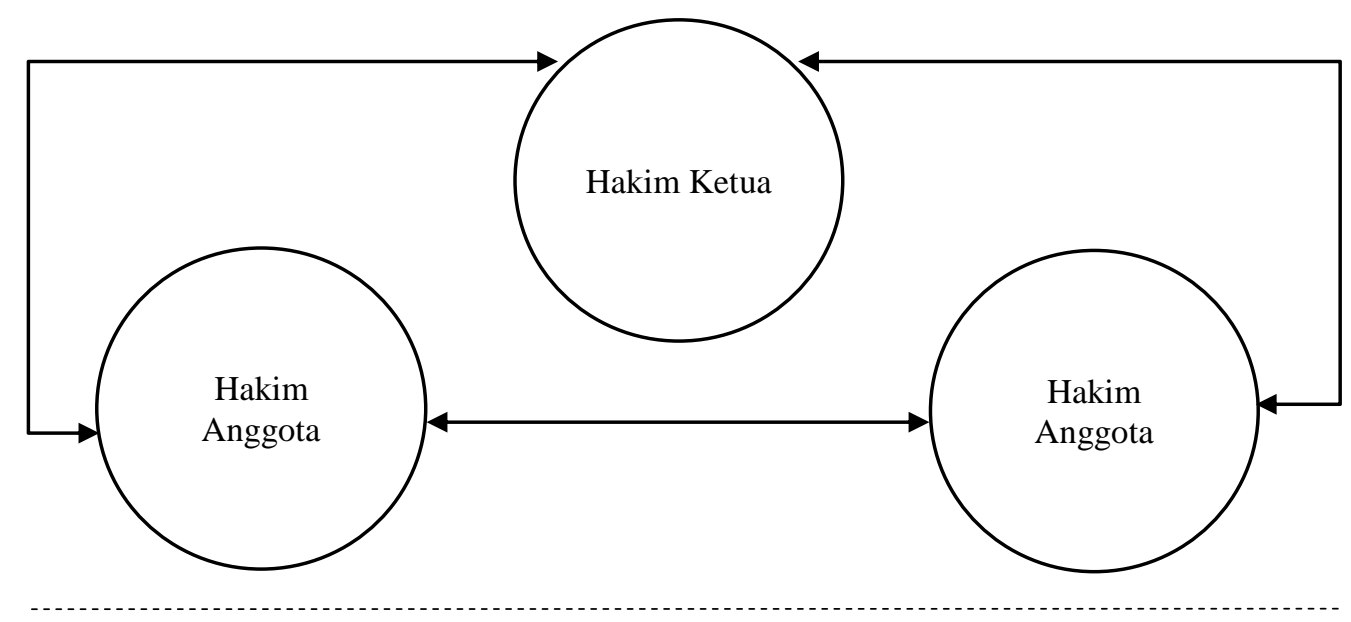

Penuntut Umum

Penasihat Hukum

Terdakwa, Saksi, Petugas

Pengunjung 
Berdasarkan Gambar 1, pemolaan komunikasi antarhakim terjadi antara hakim ketua dengan hakim anggota, hakim anggota dengan hakim anggota atau sebaliknya. Komunikasi ini menjadi penting, sebagaimana diungkapkan informan, bahwa antara hakim ketua dan hakim anggota memiliki kepentingan yang sama, meski demikian pandangan ketiganya mengenai sebuah perkara kerap berbeda. Perbedaan ini biasanya disebabkan perbedaan penilaian akan bukti dan keterangan yang disampaikan dalam persidangan. Dalam prosesnya sering ditemukan catatan atau keterangan yang berbeda, sehingga mengatasi perbedaan itu komunikasi dan masing-masing bukti menjadi penting. Informan menyampaikan catatan dalam persidangan merupakan bukti bagi pribadi untuk menilai perkara apakah memenuhi unsur-unsur yang disangkakan kepada terdakwa atau tidak.

Komunikasi antarmajelis ini mengikuti aturan kehakiman yang ada di Indonesia, aturan itu juga dalam prosesnya komunikasi antarhakim penting dalam memutuskan terdakwa. Ada beberapa hal yang menjadi landasan hakim dalam menentukan keadilan hukum bagi terdakwa. Sebagaimana yang diungkapkan oleh para informan yakni: (1) keyakinan hakim sendiri; mempertimbangkan social justice, ethical justice, dan moral justice.

Komunikasi hakim dalam persidangan, baik sidang dakwaan, sidang pemeriksaan, sidang tuntutan maupun sidang putusan melibatkan aktivitas komunikasi baik secara verbal maupun nonverbal. Komunikasi verbal yang tergambar yaitu tanya jawab, diskusi antarhakim majelis, sementara komunikasi nonverbal melalui gerakan tubuh seperti gelengan kepala menandakan tidak, anggukan kepala menandakan "ya" atau persetujuan.

Model komunikasi antarhakim dalam persidangan memiliki berbagai komponen komunikasi yang membentuk berdasarkan aspek komunikasi yang diungkapkan Hymes (Hymes, 1974) pada Tabel 1.

Tabel 1

Komponen Komunikasi Hakim Majelis dalam Persidangan

\begin{tabular}{|c|c|}
\hline $\begin{array}{l}\text { Komponen } \\
\text { Komunikasi }\end{array}$ & Komponen Komunikasi Dalam Persidangan \\
\hline Setting and Scene & $\begin{array}{l}\text { Terjadi di tempat duduk majelis hakim, di ruang sidang pengadilan/terjadi di ruang hakim } \\
\text { dengan suasana serius dan formal. }\end{array}$ \\
\hline Participants & Hakim ketua, hakim anggota. \\
\hline Ends & $\begin{array}{l}\text { Diskusi atau musyawarah alat bukti, keterangan, penilaian dan pertimbangan sampai pada } \\
\text { akhinya mengambil keputusan. }\end{array}$ \\
\hline Act & $\begin{array}{l}\text { Dimulai dengan tanya jawab, diskusi memberikan pernyataan, pertimbangan, saran, diakhiri } \\
\text { dengan simpulan memberikan putusan. }\end{array}$ \\
\hline Key & Nada bicara yang santai, kadang berbisik. \\
\hline Intrumentalities & $\begin{array}{l}\text { Bentuk komuniasi lisan dan komunikasi tulisan, verbal dan nonverbal, dilengkapi dengan } \\
\text { gelengan kepala, menandakan tidak, anggukan kepala menandakan persetujuan. }\end{array}$ \\
\hline Norm & KUHAP, ketentuan persidangan, norma interaksi, norma kejujuran, norma interaksi. \\
\hline Genre & Diskusi. \\
\hline
\end{tabular}

Sumber: Hasil Penelitian 2016-2019

\section{Model Komunikasi Penuntut Umum}

Model komunikasi penuntut umum ini terjadi manakala penuntut umum yang menangani perkara dalam persidangan lebih dari satu orang. Apabila hanya satu orang, maka komunikasi tidak terjadi antarpenuntut umum. Komunikasi antarpenuntut umum ini diperlukan terkait dengan tujuan pembuktian dalam persidangan. Berdasarkan wawancara, komunikasi lebih menonjol 
kepada koordinasi antarpenuntut umum, mengenai kesiapan persidangan, berkasberkas serta saksi yang akan dihadirkan. Dalam persidangan, penuntut umum terdiri dari kumpulan jaksa, sementara apabila individu-individu yang tergabung dalam penuntut umum disebut sebagai jaksa atau jaksa penuntut umum.

Sebelum persidangan dilakukan, komunikasi dilakukan melalui telepon, chat WhatsApp di luar ruang. Sementara apabila terjadi dalam ruang sidang ketika persidangan dilaksanakan maka lokasi komunikasi adalah di meja penuntut umum. Ketika berlangsung persidangan komunikasi antarpenuntut umum dilakukan dalam bentuk verbal dan nonverbal dengan nada yang kecil, atau komunikasi berbisik. Beberapa hal yang kerap dibisikkan dalam model penuntut umum ini mengenai pertanyaan apa yang akan disampaikan. Bentuk komunikasi tergolong santai "ahh ini bohong ni terdakwa" atau "bro, lanjut". Sementara tanda berbisik dengan menempelkan tangan di bagian hidung sebagai penghubung mulut dan telinga adalah bukti komunikasi berbisik dilaksanakan.

Komunikasi antarjaksa dalam persidangan terjadi dalam situasi formal, serius, santai, dan tenang. Sebagaimana diungkapkan oleh informan. Santai yang dimaksud adalah bahwa pembuktian yang dilakukan dalam persidangan bersifat menggali mengonfirmasi yang berkaitan dengan unsur-unsur pokok perkara yang didakwakan dalam persidangan. Sebab, penggalian informasi telah dilakukan saat penyelidikan atau penelitian perkara.

Proses komunikasi antarpenuntut umum ini biasanya dimulai ketika salah satu jaksa (apabila dalam bentuk tim) memperoleh informasi atau tanggapan dari pihak lain, misalnya perintah dari hakim ketua untuk menghadirkan saksi, maka tim ini berkoordinasi dengan jaksa lain dengan meminta petugas untuk menghadirkan saksi dalam persidangan. Proses komunikasi ini melibatkan tujuan, tujuan penuntut umum berkomunikasi dalam tim untuk mengomunikasikan hasil atau keterangan yang diperoleh oleh majelis hakim dalam persidangan.

Komunikasi penuntut umum dilakukan di ruang sidang pengadilan, khususnya di tempat duduk penuntut umum. Partisipan terdiri dari penuntut umum, dan jaksa, dalam bentuk verbal dan nonverbal. Berdasarkan identifikasi dan penjelasan dalam hasil penelitian maka model komunikasi penuntut umum dalam persidangan dapat ditunjukkan pada Gambar 2.

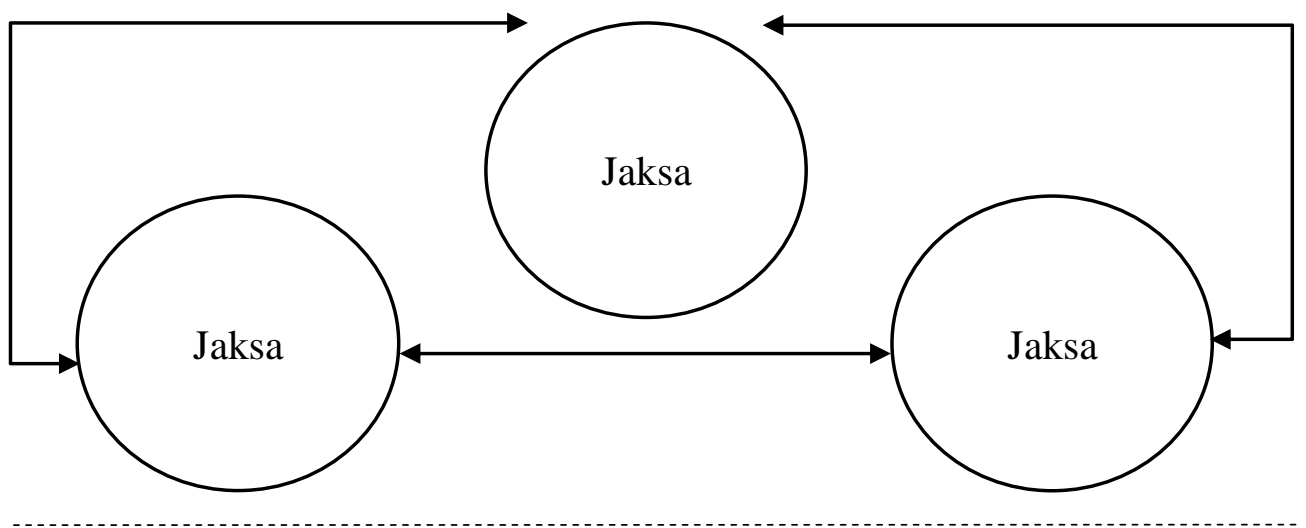

Penasihat Hukum

Terdakwa------Saksi--------Petugas
Pengunjung

Sumber: Hasil Penelitian 2016-2019

Gambar 2. Model Komunikasi Penuntut Umum dalam Persidangan. 
Berdasarkan Gambar 2, maka dapat diurai bahwa bentuk komunikasi penuntut umum dalam persidangan sebagai sebuah kelompok yang dilakukan penuntut umum dalam persidangan adalah memastikan dakwaan hingga tuntutan yang dilakukan kepada terdakwa dapat terbukti sebagaimana mestinya. Hal ini disampaikan informan saat wawancara. Sebagai sebuah tim yang memiliki tujuan yang sama, dalam mencapai tujuan itu komunikasi antarjaksa dalam kelompok penuntut umum menjadi penting, hal ini berkaitan dengan informasi baru yang digali, penyesuaian alat bukti untuk memenuhi hak-hak korban dalam persidangan. Landasan dalam menyusun dakwaan dan tuntutan adalah memastikan hak-hak korban dapat terpenuhi dan terwakili dalam persidangan, berbeda dengan penasihat hukum yang memastikan hak-hak terdakwa dalam persidangan. Tabel 2 menunjukkan komponen komunikasi yang ada dalam model komunikasi penuntut umum dalam persidangan.

Tabel 2

Komponen Model Komunikasi antar Penuntut Umum

\begin{tabular}{ll}
$\begin{array}{l}\text { Komponen } \\
\text { Komunikasi }\end{array}$ & \multicolumn{1}{c}{ Komponen Komunikasi Dalam Persidangan } \\
\hline Setting and Scene & $\begin{array}{l}\text { Terjadi di ruang sidang pengadilan, di tempat duduk penuntut umum dalam suasana } \\
\text { hening, tenang, serius. } \\
\text { Participants }\end{array}$ \\
Ends & menuntut umum, jaksa atau jaksa penuntut umum. \\
Act & Dimulai dari tanya jawab, pernyataan, pertimbangan, saran, dan melahirkan tindakan. \\
Key & Nada bicara yang santai, kadang berbisik. \\
Intrumentalities & Bentuk komuniasi lisan dan komunikasi tulisan, verbal dan nonverbal, komunikasi \\
berbisik. & KUHAP, ketentuan persidangan, norma interaksi, norma kejujuran, norma interaksi. \\
Genre & Diskusi, tanya jawab. \\
\hline
\end{tabular}

Sumber: Hasil Penelitian 2016-2019

\section{Model Komunikasi Penasihat Hukum}

Salah satu bentuk model komunikasi dalam persidangan terjadi antara penasihat hukum. Penasihat hukum menjadi salah satu partisipan komunikasi penting dalam persidangan apabila terdakwa yang disidang memiliki tuntutan hukum minimal lima tahun atau lebih dari lima tahun. Hal ini sebagaimana diatur dalam undang-undang berkaitan dengan hak terdakwa dalam persidangan. Di ruang sidang pengadilan, penasihat hukum terdiri dari pengacara yang tergabung dalam sebuah tim. Penasihat hukum terdiri dari kumpulan pengacara, sementara pengacara adalah individu yang tergabung dalam penasihat hukum.

Di ruang sidang Pengadilan Negeri Jakarta Pusat tidak semua terdakwa yang berperkara di sidang didampingi penasihat hukum. Hal ini bergantung dari proses sidang dan penggunaan hak terdakwa dalam persidangan, ada terdakwa kasus sederhana, ada terdakwa yang kasusnya rumit sehingga proses sidang menjadi panjang.

Dalam persidangan, penasihat hukum bertindak sebagai pendamping terdakwa, di mana dalam pelaksanaannya penasihat hukum mendampingi terdakwa untuk memastikan hak-hak terdakwa dalam persidangan dapat terpenuhi. Penasihat hukum memberikan pemahaman mengenai perkara dan proses perkara hingga tindak kejahatan yang dilakukan terdakwa. Sebagaimana pernyataan informan sembilan bahwa bentuk pendampingan yang diberikan berupa advokasi. Advokasi yang dimaksud adalah memberikan pemahaman tentang perkara, pasal yang disangkakan, tindakan yang harus diambil berkaitan dengan perkara yang dihadapi.

Komunikasi penasihat hukum dalam persidangan pada prinsipnya tidak berdiri 
sendiri, melibatkan partisipan komunikasi lain untuk mencapai tujuaan yang diinginkan. Tujuan tersebut berkaitan dengan "proses pembuktian terdakwa", meringankan hukuman terdakwa, membuktikan terdakwa tidak bersalah, membantu terdakwa menghadirkan buktibukti dan saksi yang meringankan dalam persidangan.

Dalam persidangan, proses lain yang terjadi adalah komunikasi antarpenasihat hukum (apabila berbentuk tim). Komunikasi ini tidak jauh berbeda dengan bentuk atau model komunikasi penuntut umum, yang membedakan adalah tujuan dan kepentingan masing-masing. Fokus dari advokasi yang terjadi dalam komunikasi dengan penasihat hukum sebagai sebuah kelompok adalah sebagaimana diungkapkan oleh informan delapan adalah memastikan hak-hak terdakwa dalam persidangan terpenuhi. Sehingga apapun hasil yang diperoleh dalam persidangan dapat menjadi keputusan yang dianggap adil.

Selain itu, fokus lain yang menjadi perhatian yang dikomunikasikan penasihat hukum dengan terdakwa dan saksi adalah untuk menyusun tindakan, strategi ataupun respon (penasihat hukum menyebutnya sebagai taktik). Taktik yang dimaksud adalah untuk merespon hal-hal apa saja yang muncul dalam proses persidangan. Entah pada keterangan saksi, keterangan terdakwa, bukti petunjuk, alat bukti, keterangan saksi ahli.

Komunikasi antar penasihat hukum terjadi dalam setting ruang sidang dan konteks proses persidangan baik sidang dakwaan sampai pada sidang putusan. Komunikasi ini terjadi dalam bentuk komunikasi verbal dan komunikasi nonverbal. Misalnya menggunakan bisikan, kode mata, dan mimik muka seperti (gelengan kepala, anggukan, tatapan, dan ekspresi muka).

Dalam persidangan terdapat aturan yang dipatuhi, tidak hanya ketentuan ketentuan dan undang-undang, selain itu juga terdapat aturan yang mengikat individu berkaitan dengan bagaimana aturan interaksi dan komunikasi dilakukan, berdasarkan uraian diatas, berikut wujud model komunikasi yang terbentuk.

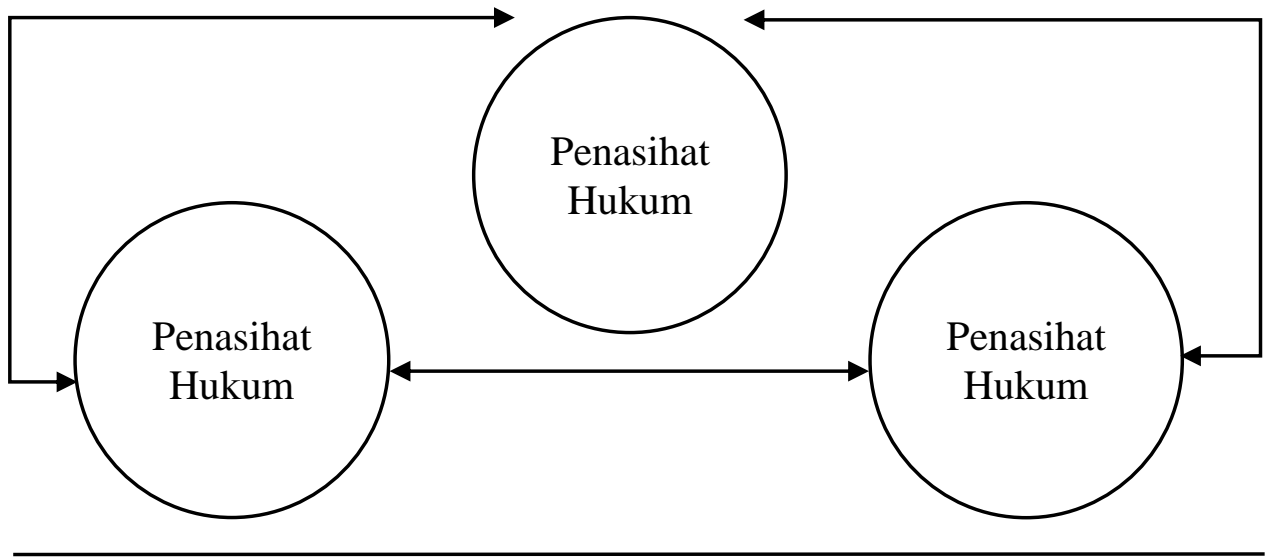

$$
\begin{gathered}
\text { Penuntut Umum } \\
\text { Terdakwa -------Saksi-------- Petugas } \\
\text { Pengunjung }
\end{gathered}
$$

Sumber: Hasil Penelitian 2016-2018

Gambar 3. Model Komunikasi Penasihat Hukum dalam persidangan. 
Berdasarkan penggambaran model komunikasi pada Gambar 3, komunikasi yang terjadi antarpengacara sebagai kelompok penasihat hukum terjadi di ruang sidang atau di sisi sebelah kiri majelis hakim. Komunikasi ini fokus pada tindakantindakan yang betujuan memastikan hak-hak terdakwa dapat terpenuhi. Pemenuhan hakhak tersebut melalui model advokasi dalam setiap proses persidangan. Baik mulai sidang dakwaan sampai pada sidang tuntutan dan sidang putusan. Advokasi dilakukan dalam bentuk tanya jawab dalam menyusun strategi (taktik) dalam persidangan. Terbentuknya model komunikasi tersebut berdasarkan identifikasi komponen komunikasi dalam persidangan dengan partisipan penasihat hukum sebagai sebuah tim. Tabel 3 menunjukkan komponen komunikasi yang teridentifikasi yang muncul dalam komunikasi penasihat hukum sebagai berikut.

Tabel 3

Komponen Komunikasi Penasihat Hukum dalam Persidangan

\begin{tabular}{ll}
\multicolumn{1}{c}{ Komponen } & \multicolumn{1}{c}{ Komponen Komunikasi dalam Persidangan } \\
Setting and Scene & $\begin{array}{l}\text { Terjadi di ruang sidang pengadilan, di tempat duduk penasihat hukum, dalam suasana } \\
\text { hening, tenang serius. }\end{array}$ \\
Participants & Antarpengacara atau tim penasihat hukum. \\
Ends & Diskusi, koordinasi, menyusun respon, mengatur tanggapan, strategi. \\
Act & Pernyataan, pertimbangan, saran. \\
Key & Nada bicara yang santai, kadang berbisik, gelengan kepala. \\
Intrumentalities & Bentuk komuniasi lisan dan komunikasi tulisan, verbal dan nonverbal. \\
Norm & KUHAP, ketentuan persidangan, norma interaksi, norma kejujuran, norma interaksi. \\
Genre & Tanya jawab dan diskusi, cerita. \\
\hline
\end{tabular}

Sumber: Hasil Penelitian 2016-2019

Berdasarkan uraian mengenai model komunikasi penegak hukum pada Gambar 1, 2, dan 3 merupakan bentuk model yang melibatkan penegak hukum pada masingmasing konteks komunikasi dan kepentingan yang terlibat dalam interaksi, yakni Model Komunikasi Penegak Hukum, model ini berisi: (1) Model komunikasi hakim; (2) Model komunikasi penuntut umum; (3) Model komunikasi penasihat hukum. Model-model tersebut memiliki komponen komunikasi sebagaimana diuraikan pada Tabel 1, 2, dan 3. Komponen komunikasi yang membentuk masing-masing model terdiri dari partisipan yang berbeda, setting yang berbeda, suasana yang sama, serta tujuan yang berbeda, namun memiliki norma dan aturan yang sama. Persamaan situasi, pengaturan dalam persidangan serta dari persamaan tujuan, maka dapat diurakan model yang menggabungkan ketiga model tesebut yakni model komunikasi antarpenegak hukum dalam persidangan.

\section{Model Komunikasi Antarpenegak Hukum dalam Ruang Persidangan}

Model komunikasi antarpenegak hukum merupakan salah satu bentuk komunikasi yang terjadi dalam persidangan. Berdasarkan hasil pengamatan dan analisis model ini melihat penegak hukum (hakim, penuntut umum, penasihat hukum) sebagai sebuah kelompok yang memiliki tujuan dan kepentingan sama, serta setting dan scene yang diciptakan juga sama. Berbeda dengan model komunikasi penegak hukum yang memandang penegak hukum (hakim, penuntut umum penasihat hukum) memilik kepetingan dan tujuan yang berbeda.

Komunikasi antarpenegak hukum ini berlangsung dalam setiap proses persidangan yang berlangsung di ruang sidang. Proses komunikasi ini terjadi dalam sidang dakwaan, sidang pemeriksaan, sidang tuntutan hingga sidang putusan. Model komunikasi ini merupakan model transaksional yang bersifat asimetris. 
Artinya dalam pembentukan model terjadi pertukaran pesan dengan tujuan mengubah sikap atau pandangan masing-masing pelaku.

Model komunikasi antarpenegak hukum dalam persidangan merupakan bentuk model komunikasi yang akan menjelaskan keterpautan majelis hakim, penuntut umum, dan penasihat hukum dalam komunikasi. Penegak hukum yang dimaksud adalah pelaku komunikasi dalam persidangan yang terdiri dari masing-masing tim yang mewakili masing-masing kepentingan. Perbedaan mendasar pada ketiga model tersebut adalah terletak pada kepentingan dan tujuan masing-masing. Masing-masing tim memiliki perbedaan, namun demikian persamaan yang muncul berkaitan dengan persamaan tujuan secara umum.

Dalam suatu peristiwa komunikasi selalu terdapat kesesuaian di antara komponen komunikasi yang membentuknya. Begitu pula model komunikasi antarpenegak hukum dalam persidangan. Pelaku komunikasi terjadi antara majelis hakim, penasihat hukum, dan penuntut umum. Terjadinya komunikasi sebagai sebuah model di antaranya disebabkan persamaan tujuan, meski kepentingan personal berbeda.

Komunikasi antarpenegak hukum secara umum melibatkan komunikasi hakim, komunikasi penuntut umum, komunikasi antarpenasihat hukum. Komunikasi ini terjadi dalam setiap peristiwa komunikasi dalam proses persidangan. Misalnya dalam sidang dakwaan, hakim memerintahkan penuntut umum menyampaikan isi dakwaan, penasihat hukum, dan terdakwa diminta hakim untuk menyimak isi dakwaan dan memberikan tanggapan atas isi dakwaan yang disampaikan.

Komunikasi ini memiliki tujuan kelompok yang sama dengan kepentingan yang berbeda, komunikasi yang terjadi biasanya disebut para informan sebagai komunikasi tiga sudut, sebagaimana diungkapkan informan bahwa asumsi komunikasi tiga sudut ini berkaitan dengan latar belakang kepentingan masing-masing penegak hukum yang berbeda, dan bertemu pada satu titik kesepakatan yakni kesepakatan hukuman yang diberikan kepada terdakwa berdasarkan barang, alat bukti, dan keterangan yang disampaikan.

Dalam prosesnya komunikasi tiga sudut yang dimaksud para informan berangkat dari persamaan titik pada praduga tak bersalah, kemudian mengarah kepada pembuktian dan keputusan. Selain itu disebut tiga sudut karena masing-masing penegak hukum mempunyai persepsi yang berbeda dan pada akhirnya persepsi yang berbeda itu harus disatukan. Penyatuan pandangan atau persepsi tersebut melibatkan cara atau strategi yang digunakan masingmasing pihak untuk saling memengaruhi sehingga tujuan dalam sidang dapat tercapai. Persoalan dalam persidangan atau komunikasi tiga sudut yang dijelaskan bukan hanya berkaitan dengan bagaimana memandang terdakwa, melainkan lebih dari itu adalah membuktikan pandangan yang sesuai dengan asas praduga tak bersalah itu dilakukan.

Model komunikasi antarpenegak hukum ini terjadi dalam setiap peristiwa komunikasi dalam persidangan. Dalam pemeriksaan saksi misalnya, majelis hakim setelah membuka sidang maka akan mempersilakan penuntut umum untuk menghadirkan saksi dalam persidangan. Kemudian hakim ketua dan hakim anggota memberikan pertanyaan yang bertujuan menemukan informasi baru atau mengklarifikasi berkas perkara. Setelah itu hakim ketua akan mempersilakan masingmasing penasihat hukum ataupun penuntut umum untuk memberikan pertanyaan kepada saksi mengenai hal-hal yang menyangkut perkara. Berdasarkan uraian di atas model komunikasi antarpenegak hukum dapat digambarkan Gambar 4.

Berdasarkan Gambar 4, bahwa model komunikasi ini terjadi antarpenegak hukum. Ada dua kategori komunikasi yang terjadi yakni komunikasi yang bersifat langsung dan komunikasi yang tidak langsung. Komunikasi langsung yang dimaksud terjadi antara majelis hakim dengan penuntut umum, majelis hakim dengan penasihat hukum. Sementara komunikasi tidak langsung terjadi antara penuntut umum dengan penasihat hukum. Sebab apabila 
ingin berkomunikasi penuntut umum dengan penasihat hukum ketika saling menanggapi harus mendapat persetujuan dari hakim majelis.

Model komunikasi antarpenegak hukum dalam persidangan ini bersifat berbeda dengan model komunikasi lainnya dalam persidangan, salah satunya dengan model pada masing-masing penegak hukum, perbedaan ini menyangkut substansi persidangan sehingga, dapat dirinci beberapa argumentasi berkaitan dengan model ini sebagai berikut:

- Pelaku komunikasi antar penegak hukum/partisipan melibatkan majelis hakim, penuntut umum, penasihat hukum.

- Pesan dalam bentuk verbal dan nonverbal. Pesan verbal menyangkut keterangan tanya jawab dalam melalui persidangan, nonverbal menyangkut penegasanpenegasan lewat nada, gerakan tubuh, pandangan mata.

- Komunikasi ini merupakan komunikasi dengan model tiga sudut, terjadi dalam bentuk komunikasi langsung dan tidak langsung, di mana apabila penasihat hukum melakukan interaksi dengan penuntut umum maka harus meminta izin kepada hakim, selain itu juga berupa pengajuan keberatan melalui interupsi dalam persidangan, melalui persetujuan hakim.

- Komunikasi ini memiliki tujuan komunikasi sama, namun memiliki kepentingan berbeda.

Komunikasi antara penegak hukum yang terdiri dari majelis hakim, penuntut umum dan penasihat hukum dilakukan dengan tujuan utama memeriksa perkara hukum. Namun dalam prosesnya ada beberapa tujuan komunikasi lain yang dilakukan mereka. Di antaranya berkomunikasi untuk membuka sidang, berkomunikasi untuk menentukan agenda dan tanggal sidang lanjutan, berkomunikasi untuk menghadirkan saksi, dan berkomunikasi untuk menghadirkan alat bukti dan saksi.
Komunikasi antara penegak hukum ini berlangsung selama proses sidang dilaksanakan. Pesan dalam model komunikasi penegak hukum ini berbentuk verbal dan nonverbal. Bentuk verbal terjadi melalui bahasa komunikasi, lewat pertanyaan hakim kepada penasihat hukum ataupun penuntut umum. Misalnya dengan tujuan pembukaan sidang, majelis hakim menanyakan "apakah sidang sudah dapat dimulai?" - "sudah yang mulia” jawab penuntut umum dan penasihat hukum. Sementara bentuk pesan nonverbal tergambar dari "anggukan kepala penuntut umum, penasihat hukum" sebagai tanda sidang sudah dapat dimulai. Selain bentuk verbal dan nonverbal dalam persidangan terdapat norma interaksi yang terjadi dalam model komunikasi ini, di antaranya aturan untuk berkata sopan dan menghargai satu sama lain. Model komunikasi tersebut terbentuk berdasarkan model komunikasi lain, yang berkaitan dengan model komunikasi masing-masing partisipan lengkap dengan anggota masing-masing.

Interaksi komunikasi dalam persidangan yang terjadi antara penegak hukum disebut juga sebagai kegiatan komunikasi profesional hukum apabila mengacu pada penelitian Arronson, Jönsson, \& Linell (1987). Namun dalam persidangan di ruang sidang pengadilan di Indonesia, pelaku yang terlibat dalam proses persidangan yang menyangkut orang-orang profesional dalam bidang hukum disebut penegak hukum. Komunikasi profesional hukum ini merupakan bentuk komunikasi gabungan dari tiga tim yang secara khusus memiliki tujuan yang bertolak belakang, namun disatukan dalam satu kelompok yang memiliki tujuan yang sama. Tujuannya adalah untuk menyelesaikan perkara hukum.

Hal ini diperkuat pula dalam hasil wawancara dengan beberapa informan. Model komunikasi profesional hukum terjadi dalam ruang sidang. Profesional hukum dianggap sebagai aktor komunikasi. Karin Aronsson, Linda Jonsson and Per Linell dalam risetnya yang berjudul The Courtroom Hearing as a Middle Ground: Speech Accommodation by Lawyers and Defendants menjelaskan bahwa profesional 
hukum merupakan pelaku komunikasi dalam peradilan. Para pelaku dalam penegakan hukum disebut sebagai profesional hukum (legal proffessional). Karin menyatakan bahwa profesional hukum yang dimaksud adalah profesional yang memiliki profesi hukum, di antaranya hakim, pengacara juga jaksa (Aronsson, Jönsson, \& Linell, 1987; Isani, 2010).

\section{Panitera}
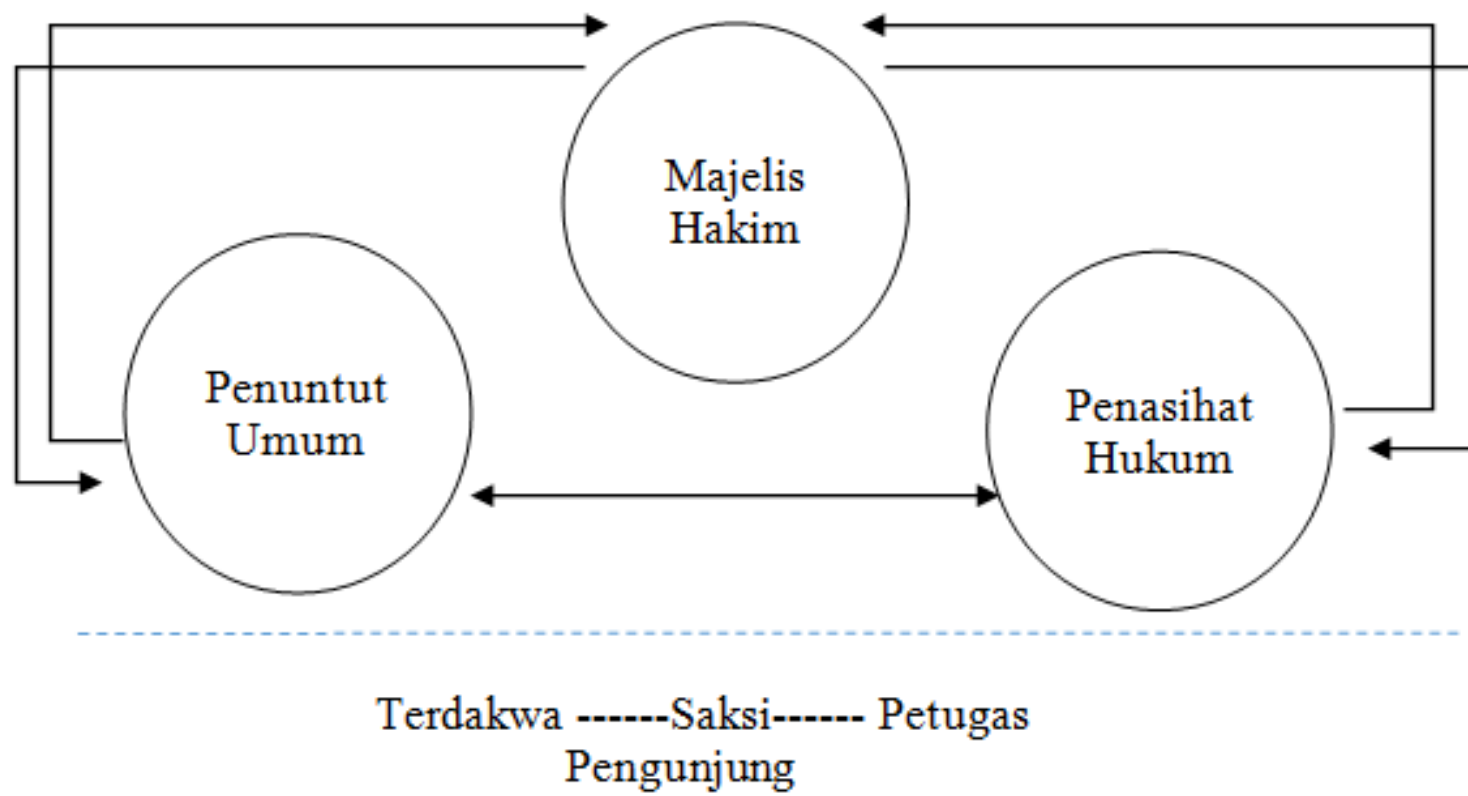

Sumber: Hasil Penelitian 2016-2019

Gambar 4. Model Komunikasi Antar Penegak Hukum dalam Persidangan.

Tabel 4

Komponen Komunikasi Penasihat Hukum dalam Persidangan

$\begin{array}{ll}\text { KOMPONEN } & \text { KOMPONEN KOMUNIKASI DALAM PERSIDANGAN } \\ \text { KOMUNIKASI } & \end{array}$

\begin{tabular}{ll}
\hline Setting and Scene & Terjadi di ruang sidang pengadilan, dalam suasana hening, tenang, serius, formal. \\
Participants & Antar majelis hakim, penuntut umum, penasihat hokum. \\
Ends & Memeriksa perkara hukum terdakwa, mengkarifikasi, mengajukan keberatan, interupsi, \\
& memutuskan terdakwa bersalah atau tidak. \\
Act & Pernyataan, pertanyaan, permohonan, perintah. \\
Key & Nada bicara tinggi, emosi, tegas. \\
Intrumentalities & Komunikasi lisan dan komunikasi tulisan. \\
Norm & KUHAP, ketentuan persidangan, norma interaksi, norma kejujuran, norma interaksi. \\
Genre & Tanya jawab.
\end{tabular}

Sumber: Hasil Penelitian 2016-2019

Berangkat dari pemahaman tersebut, dapat dinyatakan bahwa penegak hukum dalam persidangan terdiri dari profesional 152 yang memiliki profesi hukum, di mana menjadi aktor dalam proses menyampaikan pesan-pesan tentang persidangan yang 
dinyatakan dalam sidang. Komunikasi dalam sebagian besar konteks institusional sangat asimetris yang mencerminkan tatanan sosial hierarkis antara pembuat keputusan dan subjeknya. Berdasarkan penjelasan di atas, komponen komunikasi yang membentuk model komunikasi antarpenegak hukum dalam persidangan tertera pada Gambar 3.

\section{PENUTUP}

\section{Simpulan}

Berdasar pada pembahasan sebelumnya, terdapat dua model yang berkaitan dengan model komunikasi dalam ruang persidangan yaitu model komunikasi penegak hukum dalam persidangan serta model komunikasi antarpenegak hukum dalam persidangan. Model komunikasi penegak hukum dalam persidangan muncul dengan melihat penegak hukum (hakim, penasihat hukum, penuntut umum) sebagai sebuah kelompok yang berbeda, memiliki tujuan dan kepentingan, serta pengaturan yang berbeda dalam persidangan.

Sementara model komunikasi antarpenegak hukum melihat penegak hukum sebagai sebuah kelompok yang sama dan memiliki tujuan serta pengaturan yang sama dalam persidangan. Model-model komunikasi ini memiliki komponen komunikasi masing-masing dengan tujuan utama berkoordinasi dengan masing-masing tim guna menentukan strategi, cara, dan solusi yang akan diungkapkan sebagai perwakilan dari tim atau kelompok dalam persidangan.

\section{Saran}

Penelitian ini dikaji melalui etnografi komunikasi yang menghasilkan setidaknya dua model komunikasi. Karena model yang muncul didasarkan pada persamaan ataupun perbedaan peran, kepentingan, tujuan serta upaya yang dilakukan, maka sekiranya dapat dilakukan penelitian lebih lanjut mengkaji model ini lewat metode atau perspektif yang lain, misalnya menganalisis efektivitas salah satu model komunikasi dalam hal penegakan hukum dalam persidangan.

\section{DAFTAR PUSTAKA}

Aronsson, K., Jönsson, L., \& Linell, P. (1987). The courtroom hearing as a middle ground: Speech accommodation by lawyers and defendants. Journal of Language and Social Psychology, 6(2), 99-115.

https://doi.org/10.1177/0261927X870060 0202

Beach, W. A. (1985). Temporal density in courtroom interaction: Constraints on the recovery of past events in legal discourse. Communication Monographs, 52(1), 118.

https://doi.org/10.1080/036377585093760 93

Cangara, H. (2014). Pengantar Ilmu Komunikasi. Jakarta: RajaGrafindo Persada.

Chaer, A., \& Agustina, L. (2004). Sosiolinguistik: perkenalan awal. Jakarta: Penerbit PT Rineka Cipta.

Devito, J. A. (2013). The Interpersonal Communication Book. PEARSON. https://doi.org/10.1037/026727

Hymes, D. (1974). Foundations in Sociolinguistics: An Ethnographic Approach. Philadhelpia: University of Pennsylvania.

Isani, S. (2010). OF LEGAL COURTROOM ATTIRE AND THE CROSSCULTURAL EROSION OF PROFESSIONAL IDENTITY.

Littlejohn, S., \& Foss, K. A. (2009). Encyclopedia of Communication Theory. https://doi.org/10.4135/9781412959384

Masyarakat Pemantau Peradilan Indonesia (MaPPI). (2018). Komunikasi dalam Persidangan.

Mulyana, D. (2010). Metode Penelitian Komunikasi. (Revisi, Ed.). Bandung: PT. Remaja Rosdakarya.

Mulyana, D. (2013). Ilmu Komunikasi: Suatu Pengantar. Bandung: PT Remaja Rosdakarya.

Mulyana, D. (2017). METODE PENELITIAN KUALITATTIF : Paradigma Baru Ilmu Komunikasi dan Ilmu Sosial Lainnya. Bandung: PT Remaja Rosdakarya.

Saville-Troike, M. (2008). The Ethnography of Communication: An Introduction: Third Edition. The Ethnography of Communication: An Introduction: Third Edition. https://doi.org/10.1002/9780470758373 
Model Komunikasi Penegak Hukum dalam Ruang Persidangan di Pengadilan Negeri Jakarta Pusat Aan Widodo

Spradley, J. P. (2007). Metode Etnografi. Yogyakarta: Tiara Wacana. 